\title{
Penanaman Pendidikan Multikultural pada Masyarakat Melalui Pendirian Rumah Ibadah Bersama
}

\author{
Mujiyanto \\ Sekolah Tinggi Agama Buddha Negeri Raden Wijaya Wonogiri Jawa Tengah \\ mujiyanto009@gmail.com
}

\begin{abstract}
This study aims to find out how to cultivate multicultural education to the community, what lies behind the establishment of a shared house of worship in a neighborhood location of the Boyolali Regency Government, and how the conditions of harmony among religious communities in Boyolali Regency. The results of this study indicate that: (1) Multicultural education has been going well and has been socialized by religious leaders and leaders through various formal and non-formal activities in places of worship and in schools; (2) Establishment of places of worship on the initiative of the Boyolali Regent and supported by religious and masayarak leaders, with the aim of building togetherness to overcome differences, and to create harmony of religious life; (3) Religious harmony in Boyolali Regency has been going well, there has never been a conflict between followers of different religions.
\end{abstract}

Keywords: Multicultural Education, Establishment of Houses of Worship, Harmony of religious communities

\begin{abstract}
Abstrak. Penelitian ini bertujuan untuk mengetahui bagaimana cara penanaman pendidikan multikultural kepada masyarakat, apa yang melatarbelakangi pendirian rumah ibadah bersama dalam satu lokasi lingkungan Pemerintah Kabupaten Boyolali, dan bagaimana kondisi kerukunan hidup antar umat beragama di Kabupaten Boyolali. Hasil penelitian menunjukkan bahwa: (1) Pendidikan multikultural sudah berjalan dengan baik dan sudah disosialisasikan oleh para tokoh dan pemuka agama melalui berbagai kegiatan baik formal maupun nonformal di rumah ibadah maupun di sekolah-sekolah; (2) Pendirian rumah ibadah atas prakarsa Bupati Boyolali dan didukung oleh para tokoh agama dan masyarakat, dengan tujuan untuk membangun kebersamaan mengatasi perbedaan, serta untuk menciptakan kerukunan hidup umat beragama; (3) Kerukunan Hidup Umat beragama di Kabupaten Boyolali sudah berjalan baik, tidak pernah ada konflik diantara penganut agama yang berbeda.
\end{abstract}

Kata Kunci : Pendidikan Multikultural, Pendirian Rumah Ibadah, Kerukunan umat beragama 
Philanthrophy Journal of Psychology

Vol 2 Nomor 2 (2018), 80-87

ISSN 2580-6076 (Print), ISSN 2580-8532 (Online)

\section{Pendahuluan}

Secara kontekstual dan imperatif, hakikat dan tujuan pendidikan nasional harus merepresentasikan permasalahan kondisi objektif masyarakat bangsanya, representasi dari kebutuhan masyarakat, dan manifestasi tipologis masyarakatnya. Pemikiran ini sejalan dengan pandangan UNESCO, bahwa tujuan pendidikan adalah manifestasi hasil refleksi filosofi tentang manusia, eksistensi manusia dalam konteks sejarahnya dan tentang sistem hubungan manusia dengan alam serta masyarakat di mana dia hidup, berkreasi, dan berbuat (Hammel, UNESCO, 1977). Untuk di Indonesia ditambah dengan hubungan manusia dengan Tuhannya.

Fakta yang terjadi, dengan semakin majunya zaman yang diiringi majunya ilmu pengetahuan dan teknologi, modernisasi peradaban manusia, serta semakin banyaknya tuntutan kehidupan manusia yang harus dipenuhi, maka semakin renggang hubungan kekerabatan antar sesama manusia. Demikian pula rasa kekeluargaan yang berbeda latar belakang sosial ekonomi, agama, suku, ras, adat dan budaya, menipiskan sikap tenggang rasa, berkurangnya sikap toleransi dan menghargai perbedaan dan mengakui keberadaan kelompok-kelompok minoritas. Hal ini terlihat dengan jelas fenomena yang terjadi bahwa sikap persaudaraan dalam ke-bhineka-an menjadi sesuatu yang sulit didapat.

Selain melalui pendidikan, untuk menanamkan pendidikan multikultural di kalangan masyarakat, perlu adanya sarana fisik atau infrastruktur. Dalam hal ini perlu dibangun rumah ibadah secara bersama dalam lokasi yang sama (berdekatan), untuk mencerminkan bahwa dalam perbedaan akan ditemukan sebuah kekuatan yang begitu besar, dalam perbedaan dapat terjadi keharmonisan, dalam perbedaan tidak menimbulkan masalah.

Agama yang berkembang di Kabupaten Boyolali sudah terjadi kerukunan yang relatif baik, tidak ada gejolak diantara penganut agama yang berbeda. Disamping karena masyarakatnya sudah terbangun pola pikir inklusif, hal tersebut ditunjang karena adanya pendirian rumah ibadah secara bersama dan berdekatan di satu lokasi yang difasilitasi oleh Pemerintah Kabupaten Boyolali. Selain itu di Kabupaten Boyolali terdapat Forum kerukunan Umat Beragama (FKUB). Sehingga cita-cita luhur bangsa Indonesia untuk menciptakan Tri Kerukunan Umat beragama bisa tercapai, yakni kerukunan intern umat beragama, kerukunan antar umat bergama, dan kerukunan antar penganut beragama dengan pemerintah.

Rumusan Masalah dari penelitian ini adalah untuk mengetahui bagaimana cara menanamkan Pendidikan Multikultural Melalui Pendirian Rumah Ibadah Bersama kepada 
Philanthrophy Journal of Psychology

Vol 2 Nomor 2 (2018), 80-87

ISSN 2580-6076 (Print), ISSN 2580-8532 (Online)

masyarakat Boyolali, apa yang menjadi dasar pendirian rumah ibadah bersama dalam satu lokasi Pemerintah Kabupaten Boyolali, dan bagaimana kondisi kerukunan hidup antar umat beragama.

\section{Pendidikan Multikultural}

Meminjam pendapat Andersen dan Chuser (1994), bahwa pendidikan multikultural dapat diartikan sebagai pendidikan mengenai keragaman budaya. Kemudian Banks (1993) mendefinisikan pendidikan multikultural sebagai pendidikan untuk people of color. Artinya, pendidikan multikultural akan mengeksplorasi perbedaan sebagai keniscayaan (anugerah Tuhan). Kemudian bagaimana kita mampu mensikapi perbedaan tersebut dengan penuh toleran dan semangat egaliter. Menurut pendapat Muhaemin (2004), secara sederhana pendidikan multikultural dapat didefinisikan sebagai pendidikan tentang keragaman kebudayaan dalam meresponi perubahan demografis dan kultural lingkungan masyarakat tertentu atau bahkan dunia secara keseluruhan (global). Pendidikan berwawasan multikultural dapat diartikan suatu pendidikan yang mengapresiasi keragaman budaya sebagai realitas objektif dalam suatu kehidupan masyarakat. Dalam praktik pendidikan berwawasan multikultural ingin mengeksplorasi perbedaan sebagai keniscayaan, dan menciptakan budaya akademik yang toleran dan inklusif (Machfud, 2005)

Banks (1994) menjelaskan, bahwa pendidikan multikultural memiliki beberapa dimensi yang saling berkaitan satu dengan yang lain, yaitu: Pertama, Content Integration, yaitu mengintegrasikan berbagai budaya dan kelompok untuk mengilustrasikan konsep mendasar generalisasi dan teori dalam mata pelajaran/disiplin ilmu. Kedua, The knowledge construction process, yaitu membawa siswa untuk memehami aplikasi budaya ke dalam semua mata pelajaran (disiplin). Ketiga, an equity paedagogy, yaitu menyesuaikan metode pengajaran dengan cara belajar siswa yang beragam baik dari segi ras, budaya (culture) ataupun sosial (social). Keempat, prejudice reduction, yaitu mengidentifikasi karakteristik ras siswa dan menentukan metode pengajaran mereka. Kemudian, melatih kelompok untuk berpartisipasi dalam kegiatan olah raga, berinteraksi dengan seluruh staf dan siswa yang berbeda etnis dan ras dalam upaya budaya akademik yang toleran dan inklusif. 
Philanthrophy Journal of Psychology

Vol 2 Nomor 2 (2018), 80-87

ISSN 2580-6076 (Print), ISSN 2580-8532 (Online)

Menurut Tilaar (2002), pendidikan multikultural berawal dari berkembangnya gagasan dan kesadaran tentang "interkulturalisme" seusai perang dunia kedua. Kemunculan gagasan dan kesadaran "interkulturalisme" ini, selain terkait perkembangan politik internasional menyangkut HAM, kemerdekaan dari kolonialisme dan dislriminasi rasial dan lain-lain, juga karena meningkatnya pluralitas (keberagaman) di negara-negara barat sendiri sebagai alibat dari peningkatan migrasi dari negara-negara baru merdeka ke Amerika dan Eropa.

\section{Pendidikan Berwawasan Multikultural}

Memberlakukan pendidikan berwawasan multikulturalisme membawa konsekuensi perubahan paradigma manajemen dan kurikulum pendidikan. Masalah manajemen pendidikan di sini adalah bagaimana mengubah orientasi; (a) dari penyelenggaraan pendidikan dengan dominasi kekuasaan birokrasi menjadi dominasi kekuasaan akademi; (b) dari pendekatan seragam ke pendekatan beragam (multikultural), demokrasi terbuka; (c) dari serba pusat ke distribusi daerah; (d) dari kecenderungan berorientasi global beralih ke orientasi kepentingan nasional dan regional. Sedangkan masalah kurikulum adalah bagaimana menyusun institusional curriculum di semua jenjang pendidikan dapat mengadopsi nilai-nilai pluralitas kedaerahan, dengan prinsip menjunjung tinggi khasanah budaya nasional dan kearifan lokal.

Pelaksanaan pendidikan berwawasan multikulturalisme di Indonesia dapat menggunakan model yang disarankan Gorski, pendidikan multikultural dapat mencakup tiga jenis transformasi: (1). transformasi diri, (2).transformasi sekolah dan proses belajar dan pembelajaran, (3) transformasi masyarakat (Mahfud, 2005).

Karena itu kita diberi petunjuk untuk menguji, apakah yang sampai kepada kita sesuai dengan Sutta dan Vinaya (D. II, 123-125). Jika diibaratkan dengan sebatang pohon, tanaman itu tumbuh berkembang dengan bercabang dan beranting. Bagaimanapun semua cabang dan ranting tersebut dikenali sebagai bagian dari pohon yang sama, yang berasal dari biji yang satu. Menurut pernyataan Buddha sendiri, "Sebagaimana halnya dengan samudera raya yang hanya mempunyai satu rasa, yaitu rasa garam, demikian pula dharma hanya mempunyai satu rasa, yaitu rasa kebebasan" (Ud. 56).

\section{Pendirian Rumah Ibadah}


Philanthrophy Journal of Psychology

Vol 2 Nomor 2 (2018), 80-87

ISSN 2580-6076 (Print), ISSN 2580-8532 (Online)

Pada 2005, Departemen Agama bersama dengan Departemen Dalam Negeri, Kejaksaan Agung, dan instansi pemerintah lainnya mengadakan pertemuan membahas perubahan SKB tahun 1969. Setelah melalui diskusi panjang, dan disetujui oleh perwakilan pusat agama "resmi" yang ada di Indonesia, pada 21 Maret 2006 dikeluarkan Peraturan Bersama Menteri Agama dan Menteri Dalam Negeri Nomor 9 dan 8 Tahun 2006 tentang Pedoman Pelaksanaan Tugas Kepala Daerah/Wakil Kepala Daerah dalam Pemeliharaan Kerukunan Umat Beragama, Pemberdayaan Forum Kerukunan Umat Beragama, dan Pendirian Rumah Ibadat (selanjutnya disebut sebagai PBM No. 9 \& 8 Tahun2006) (Ali-Fauzi, dkk, 2011).

Tujuan dikeluarkannya peraturan ini, selain untuk menggantikan SKB Menteri Dalam Negeri dan Menteri Agama No. 1 Tahun 1969 yang dinilaisangat diskriminatif, adalah juga untuk merespon berbagai keluhan yang dirasakan masyarakat atas maraknya pendirian rumah ibadat umat minoritas di wilayah umat mayoritas serta beragamnya peraturan pendirian rumah ibadat di berbagai daerah pasca pemberlakuan otonomi daerah, yang pada akhirnya membuat umat beragama kesulitan dalam mendirikan rumah ibadat mereka.

Rumah ibadah yang dimaksud di sini adalah rumah ibadah agama Islam, Kristen, Katolik, Hindu, Buddha, dan Konghucu, yang didirikan oleh Pemerintah Kabupaten Boyolali dengan dukungan tokoh agama, tokoh masyarakat, dan para penganut/pemeluk umat beragama. Rumah ibadah yang dibangun oleh Pemerintah Boyolali ini, disamping sebagai sarana untuk menciptakan suasana kerukunan umat beragama, juga untuk memberikan wawasan pendidikan multikultural pada masyarak Boyolali khususnya dan masyarakat luas pada umumnya, betapa pentingnya kerukunnan umat beragama untuk membangun suatu bangsa yang besar dan kuat, sehingga menjadi contoh bagi kehidupan masyarakat dunia.

\section{Kerukunan Hidup Beragama}

Kerukunan hidup beragama adalah suatu kondisi dimana semua golongan agama bisa bersama-sama secara damai tanpa mengurangi hak dan kebebasan masing-masing untuk menganut dan melaksanakan kewajiban agamanya. Kerukunan yang dimaksud bukan berarti penganut agama yang satu tidak merasa perlu atau menahan diri untuk melibatkan persoalan keberagaman dengan pihak lain, karena kebersamaan menghendaki tenggang rasa, yang hanya benar-benar dimungkinkan jika saling memahami. 
Philanthrophy Journal of Psychology

Vol 2 Nomor 2 (2018), 80-87

ISSN 2580-6076 (Print), ISSN 2580-8532 (Online)

Kerukunan akan bisa dicapai apabila setiap golongan agama memiliki prinsip "setuju dalam perbedaan". Setuju dalam perbedaan berarti orang mau menerima dan menghormati orang lain dengan seluruh aspirasi, keyakinan, kebiasaan, dan pola hidupnya, menerima dan menghormati orang lain dengan kebebasannya untuk menganut keyakinan agamanya sendiri. Memelihara kerukunan hidup umat beragama tidaklah berarti mempertahankan status quo sehingga menghambat kemajuan masing-masing agama. Kerukunan itu harus dilihat dalam konteks perkembangan masyarakat yang dinamis, yang menghadaoi beraneka ragam tantangan dan persoalan.

\section{Metode}

Penelitian ini menggunakan pendekatan kualitatif dengan menggunakan model studi kasus. Lokasi di Pemerintah Kabupaten Boyolali. Datanya adalah tentang penanaman pendidikan multikultural melalui pendirian rumah ibadah bersama di satu lokasi. Sumber datanya langsung dan tidak langsung. Teknik opengumpulan data dengan ofservasi, wawancara dan dokumentasi. Penentuan informan dilakukan secara purposive, yakni informan yang akan diwawancarai adalah orang yang diyakini mampu memberikan informasi atau data yang diperlukan dalam penelitian ini. Teknik analisis datanya menggunakan analisis interaktif.

\section{Hasil dan Diskusi}

\section{Penanaman Pendidikan Multikultural di Masyarakat}

Hasilnya: baik itu tokoh agama, umat/penganut, dan pihak pemerintah tentang penanaman pendidikan multikultural pada masyarakat, khususnya masyarakat boyolali kesimpulannya sama. Para tokoh agama telah mensosialisasikan tentang keberagaman dan perbedaan di kalangan masyarakat melalui berbagai even keagamaan masing-masing.

\section{Pendirian Rumah Ibadah Bersama dalam Satu Lokasi}

Hasilnya: Pemerintah Kabupaten Boyolali sangat mendukung pendirian rumah ibadah dalam satu lokasi dan yang memprakarsai, bahkan memberikan bantuan dana untuk pendirian masing-masing tempat ibadah. Dan para tokoh agama juga mendukung, serta para penganut masing-masing agama juga sangat mendukung. 
Philanthrophy Journal of Psychology

Vol 2 Nomor 2 (2018), 80-87

ISSN 2580-6076 (Print), ISSN 2580-8532 (Online)

\section{Kerukunan Hidup Umat Beragama}

Hasilnya: kondisi kerukunan hidup umat beragama di Kabupaten Boyolali sudah cukup baik. Dimana semua golongan agama bisa bersama-sama secara damai tanpa mengurangi hak dan kebebasan masing-masing untuk menganut dan melaksanakan kewajiban agamanya.

\section{Simpulan}

Berdasarkan data, hasil analisis, dan pembahasan, dapat disimpulkan sebagai berikut:

(1) Bahwa penanaman pendidikan multikultural di masyarakat Boyolali sudah berjalan dengan baik, yang dilakukan oleh tokoh agama dan pendidik melalui berbagai kegiatan, baik melalui kegiatan keagamaan di rumah ibadah maupun melalui kegiatan kebersamaan lintas agama. (2) Bahwa pendirian rumah ibadah bersama dalam satu lokasi di lingkungan Pemerintah Kabupaten Boyolali berdasarkan prakarsa Bapak Bupati, yang didukung oleh para tokoh agama dan masyarakat, dengan Anggaran Pendapatan Belanja Daerah (APBD) Kabupaten Boyolali, yang bertujuan untuk membangun kebersamaan dalam perbedaan yang tujuan utamanya adalah untuk menciptakan kerukunan antar umat beragama. (3) Kerukunan antarumat beragama di masyarakat Boyolali sudah berjalan dengan baik, tidak ada konflik karena sudah saling memahami dan menghargai adanya perbedaan dan menjalankan ajarannya sesuai dengan agama dan keyakinannya masing-masing.

\section{Daftar Pustaka}

Alamsjah, RP. (1982.) Pembinaan Kerukunan Hidup Umat Beragama. Jakarta: Departemen Agama.

Asry, Y, ed. (2006). Pendirian Rumah Ibadat: Pelaksanaan Peraturan Bersama Menteri Agama dan Menteri Dalam Negeri No. 9 dan 8 Tahun 2006. Jakarta: Puslitbang

Barker, C. (2015). Cultural Studies. Bantul: Kreasi Wacana.

Harkiman. (1994). Menuju Peningkatan Kerukunan Hidup Beragama di Indonesia: Sebuah Gagasan Buddhis. Makalah pada Musyawarah Cendikiawan Antaragama. Medan.

Kadi, A dkk. (2014). Dasar-Dasar Pendidikan. Jakarta: Kencana Prenadamedia Group.

Krishnanda, WM. (2003). Wacana Buddha-Darma. Jakarta

Machfud, C. (2016). Pendidikan Multikultural. Yogyakarta: Pustaka Pelajar.

Miftahul, C. (2003). Pendidikan Multikultural dan Implementasinya dalam Pendidikan. Jurnal Cendekia, Vol. 3, No. 2 Juli-Desember 2003.

Muhaemin, E. (2004). Multikulturalisme dan Pendidikan Multikultural.

Ramayulis. (2015). Dasar-Dasar Kependidikan: Suatu Pengantar Ilmu Pendidikan. Jakarta: Kalam Mulia.

Riyanto, FXEA. (1995). Dialog Agama Dalam Pandangan Gereja Katolik.Yogyakarta: Kanisius. Slamet. (2013). Metode Penelitian Kualitatif (Pendekatan Studi Kasus). Surakarta: UNSPress. 
Philanthrophy Journal of Psychology

Vol 2 Nomor 2 (2018), 80-87

ISSN 2580-6076 (Print), ISSN 2580-8532 (Online)

The Wahid Institiute. (2008). Laporan Tahunan The Wahid Institute 2008 Pluralisme Beragama/Berkeyakinan di Indonesia: Menapaki Bangsa yang Kian Retak. Jakarta: The Wahid Institute dan Yayasan Tifa.

Tilaar, H.A.R. (2002). Perubahan Sosial dan pendidikan: Pengantar Paedagodik Transformatif untuk Indonesia. Jakarta: Grasindo.

Tim Reality. (2008). Kamus Terbaru Bahasa Indonesia. Surabaya: Reality Publisher.

Tim Penyusun. (2003). Undang-Undang No 20 Tahun 2003 tentang Sistem Pendidikan Nasional. Jakarta.

Widisuseno, I. (2006). Pengembangan MPK dalam Perspektif Filosofis. Makalah SIMNAS MPK IV. UNS Surakarta.

, (2004). Dari Pendidikan Kewargaan hingga Pendidikan Multkultural : Pengalaman Indonesia. Edukasi: Jurnal Penelitian Pendidikan Agama dan Keagamaan, Vol. 2, No. 4, tahun 2004. 